\begin{tabular}{ll}
\hline & $\begin{array}{l}\text { Kastamonu Eğitim Dergisi } \\
\text { Kastamonu Education Journal }\end{array}$ \\
$\begin{array}{l}\text { Eylül 2019 Cilt:27 Sayı:6 } \\
\text { kefdergi.kastamonu.edu.tr }\end{array}$ & Başvuru Tarihi/Received: 08.06 .2018 \\
Kabul Tarihi/Accepted: 24.09 .2018 \\
Dol: $10.24106 /$ kefdergi.3142
\end{tabular}

\title{
Öğretmen Adaylarının Eğitim Felsefesi İnançları ve Demokratik Tutumları Arasındaki Ílişki
}

\section{The Relationship Between Preservice Teachers' Beliefs of Educational Philisophy and Their Democratic Attitudes}

\section{Öz}

\author{
Işıl SÖNMEZ EKTEM ${ }^{1}$
}

Bu araştırmanın amacı, öğretmen adaylarının eğitim felsefesi inançlarını belirlemek ve eğitim inançları ve demokratik tutumları arasındaki ilişkiyi ortaya koymaktır. Nicel araştırma yöntemine göre desenlenen bu araşttrma, betimsel nitelik taşımaktadır. Araştırmanın çalışma grubunu Necmettin Erbakan Üniversitesi Eğitim Fakültesinde öğretim görmekte olan toplam 263 öğretmen adayı oluşturmuştur. Araştırma verilerinin toplanmasında Yılmaz, Altınkurt, Çokluk (2011) tarafindan geliştirilen "Eğitim inançları Ölçeği" ve Gözütok (1995) tarafindan geliştirilen "Demokratik Tutum Ölçeği" kullanılmıştir. Verilerin analizinde betimsel istatistikler, Mann Whitney U ve Spearman Sıra Farkları Korelasyon Katsayısı kullanılmıştır. Araştırma bulgularına göre öğretmen adaylarının en çok varoluşşu ve ilerlemeci eğitim felsefesini benimsedikleri; eğitim felsefelerinin cinsiyet ve öğretmenlik programına göre farklıık gösterdiği belirlenmiştir. Öğretmen adaylarının eğitim felsefeleri ile demokratik tutumları arasında anlamlı ilişkiler bulunmuştur.

Anahtar Kelimeler: eğitim felsefesi inançları, demokratik tutum, öğretmen adayları

\section{Abstract}

The purpose of this study is to determine preservice teachers' beliefs concerning philosophy of education and reveal the relationship between their educational beliefs and democratic attitudes. This study, which was designed according to the quantitative research method, is of a descriptive nature. The sample group of the study consists of a total of 263 students attending Necmettin Erbakan University Education Faculty. "Educational Beliefs Scale" developed by Yılmaz, Altınkurt, Çokluk (2011) and "Democratic Attitude Scale" developed by Gözütok (1995) were used to collect the research data. Descriptive statistics, Mann Whitney U and Spearman's Rank Correlation Coefficient were used to analyze the data. According to the research findings, the preservice teachers adopted the existentialist and progressivist education philosophies most and it was found that their education philosophies exhibited variation on the basis of gender and the teaching program. Significant relationships were found between preservice teachers' education philosophies and their democratic attitudes.

Keywords: beliefs of educational philosophy, democratic attitudes, preservice teachers 


\section{Extended Abstract}

Purpose: Philosophy enables us to be aware of our beliefs and values, namely our own selves, and is a process of establishing a bond on the basis of reality (a process of establishing bonds based on grounding of reality) (Demirel, 2003). The relationship between philosophy and education is both multi-dimensional and dates back to very old times, as far as is known, to Ancient Greeks. Effective education of individuals has been adopted by mankind as one of the most important ideas and practices for centuries (de,2007).

Generally, educational philosophy is a field of information that investigates human beings and problems surrounding mankind's historical, social and cultural existence, defines human beings using the information it has gathered from here, in their special environment and on the basis of universal criteria and proposes an understanding of education in accordance with this definition (Akyüz, 1991). In a way, education is a field of application for philosophy and philosophy can correct and improve itself by the help of what it has learned from the application. In addition, education enables philosophy to develop by offering new and scientific information, thereby allowing new fields to appear in it (Kaygısı, 1997). This field attempts to explain problems that prevent education, and concepts, ideas and principles that guide education (Ergün,2014).

All educators consciously or unconsciously possess a certain philosophy of education. Therefore, teachers' distances or proximities to different educational philosophies functionally affect how students will be educated (YIImaz, Altinkurt and Çokluk 2011). Although teachers are not educated in accordance with an educational philosophy in their preservice education, they develop some fundamental views and beliefs concerning education as a holistic result of the education they have received. In addition to the education they have received, factors such as teachers' points of views of life and phenomena, the home environment where they live and their school environment all play a part in the formation of these views and beliefs. These views and beliefs on the part of teachers concerning education are the most important determinants of the quality of the education they offer to students (Doğanay, Sarı, 2003). In particular, individuals' beliefs are reflected, by creating a holistic construct, in their behaviors in the form of behaving in a certain way and affect their attitudes (Deryakulu, 2004)

This study aimed to describe preservice teachers' beliefs of educational philosophy on the basis of some variables and reveal the relationship between their educational philosophy beliefs and their democratic attitudes. Within the framework of this purpose, answers were sought to the following questions:

1. To what extent do preservice teachers agree with beliefs of educational philosophy

2. Do preservice teachers' educational beliefs vary by their gender?

3. Do preservice teachers' educational beliefs vary by the teaching programs they attend (education faculty/ pedagogic formation certificate program)?

4. What kind of a relationship exists between the educational philosophies preservice teachers favor and their democratic attitudes?

Research Model: The relational screening model was used in the study. This model is intended to determine variation between two or more variables and the extent of this variation. Two different analyses can be made in relational studies. These are correlation type relationships and relationships obtained through comparison (Karasar, 2006). In this study, the educational philosophies preferred by preservice teachers were described; preservice teachers' educational philosophy preferences were compared in terms of gender and teaching programs they attended and the relationship between them was investigated; finally, correlations were calculated to determine the relationship between their educational philosophy preferences and their democratic attitudes.

The Sample Group: The sample group of the study consisted of students attending Necmettin Erbakan University Education Faculty and those attending the Pedagogical Formation Certificate Program in the 2017-2018 academic.

Data Collection Tools: "Educational Beliefs Scale" developed by Yılmaz, Altinkurt, Çokluk (2011) and "Democratic Attitude Scale" developed by Gözütok (1995)" were used to collect the research data.

Data Analysis: Descriptive statistics were used in this study to determine preservice teachers' beliefs of educational philosophy. Before beginning the analyses, whether the responses preservice teachers gave to the scales met assumptions of normality or not was checked; upon seeing that they did not meet the assumptions of normality, nonparametric tests were used. Descriptive statistics were used to determine the overall picture of preservice teachers' educational philosophy beliefs; Mann Whitney $U$ test was used to compare their educational philosophy beliefs in terms of gender and teaching programs, and Spearman's Rank Correlation Coefficient was used to determine the relationship between their education philosophy preferences and democratic attitudes.

Findings and Comments: According to the findings obtained from the study, the educational philosophies which preservice teachers preferred with the greatest percentage were existentialism, progressivism, perennialism, reconstructivism and essentialism, respectively. While existentialism and progressivism were preferred the most, perennialism was preferred the least. Existentialism generally supports an understanding of education that gains

| Kastamonu Eğitim Dergisi, 27(6), 2019| 
individuals freedom by bringing human factor into the foreground. It enables students to be raised as learners who are independent and responsible for their own learning and adopts an approach where the relationship between the teacher and the students is very close and authority of the teacher is removed (Ersözlü, 2009).The purpose of education in the progressivist educational philosophy, on the other hand, is to prepare students actively for changing world conditions (Tuncel, 2004). In this context, it is gratifying to see that preservice teachers, who are teachers of the future, believe in student-centered education because these beliefs will shape up future practices.

According to another finding of the study, preservice teachers' educational philosophies exhibit a significant difference in favor of male preservice teachers in the perennialism subdimension in terms of gender. It can be said on the basis of this finding that male preservice teachers better adopted the perennialist educational philosophy compared with female preservice teachers.

Educational philosophies which preservice teachers preferred differ in all of the subdimensions in terms of the teaching programs. When their ranking averages are taken into consideration, it can be said that preservice teachers attending the pedagogic formation certificate program are more inclined towards progressivist, existentialist, reconstructivist and perennialist educational philosophies compared with preservice teachers attending the education faculty. On the other hand, preservice teachers attending the education faculty better adopted the essentialist educational philosophy compared with preservice teachers attending the pedagogic formation certificate program. This situation can be interpreted to mean that preservice teachers receiving pedagogic formation education have better adopted contemporary educational philosophies, and that they have a more student-centered point of view in regard to teaching practices compared with preservice teachers attending the education faculty.

According to the research findings, there were significant relationships between preservice teachers' educational philosophies and their democratic attitudes. There was a low level but positive correlation between their existentialist educational philosophy beliefs and their democratic attitudes; on the other hand, there was a low level and negative correlation between essentialist educational philosophy beliefs and their democratic attitudes. According to these findings, as preservice teachers' existentialist educational philosophy beliefs increased, their democratic attitudes also increased, whereas their democratic attitude scores decreased as their essentialist educational philosophy beliefs increased.

The results obtained from the study reveal that there is a positive correlation between the existentialist educational philosophy belief and democratic attitudes. In other words, as the belief in finding the truth by offering students different alternatives in education and enabling them to make their own choices increased, positive attitudes in the form of respect for rights, respect for personality, justice, equality, tolerance and cooperation also increased.

According to another finding, a negative correlation was observed between the essentialist educational philosophy belief and democratic attitude scores. According to this, as the importance attached in education to a teacher-centered education and the belief in discipline increased, democratic attitude scores decreased.

The following suggestions can be made on the basis of these findings:

Qualitative studies conducted concerning differentiation of preservice teachers' educational philosophies in ter$\mathrm{ms}$ of the programs they are attending will be useful especially to determine the sources of the educational beliefs of preservice teachers attending education faculties. 


\section{Giriş}

Felsefe, insanın evren ve evrenin insanlarla ilişkisi üzerine sistematik, derinlemesine ve spekülatif (tasavvuri) düşünmesi sonucunda oluşmuş bir bilgi alanıdır (Gutek, 2001). Cevizci (2015)’ye göre felsefe, hayatı ve dünyayı görünüşlerin ötesine geçerek anlamlı kılma çabası olarak tanımlanır. Felsefeyi felsefe yapan şey, felsefi problemlere filozoflar tarafindan getirilmiş çözümleri okumaktan veya felsefe bilmekten ziyade, tefekkür, sorgulama ve tartşmadır (Cevizci, 2015). Felsefe her bilim dalındaki problemlerle ilgili tutarlı görüşler geliştirmeye çalışır. Bu durumda her bilim dalı felsefenin bir alt disiplini olur (Çalışkan, 2018). Diğer bir çok alan ile ilişkisi olan felsefenin, eğitim felsefesi ile de yakından ilşikisi bulunmaktadır. Eğitim ve felsefe arasındaki ilişkinin yakınlığı konusunda John Dewey "aslında tüm felsefe, eğitim felsefesi olarak düşünülebilir" diyordu (Güzey, 1998). Eğitim ve felsefenin örtüşebileceğine yönelik bir yorumu ifade eden bu yaklaşım, felsefenin insana dönük ya da insan merkezli yapısını vurgulayarak eğitimin felsefi bir bakışla gerçekleşmesi gerektiğini öngörmektedir (Hesapçığlu ve Akdağ, 2007). Eğitim sistemlerinin bireysel, toplumsal ve evrensel bilgi ve değerler doğrultusunda nasıl yapılandırılacağı tüm ülkelerde önemli bir problem alanını oluşturmaktadır. Ülkeler bu soruna eğitim politikaları aracılığıyla çözüm getirmeye çalışılar. Eğitim politikaları ve bunların uygulamaya konuluş biçimlerinin temelinde ise eğitim felsefesi yatar (Helvacı, 2007). Eğitim felsefesi, eğitimin kapsamı içinde yer alan; öğretmen, öğrenci, öğretimin içeriği, öğretim faaliyetleri, eğitim yolu ile kazandırılmak istenen değer ve tutumları konu edinir (Cevizci, 2015). Eğitim yeni ve bilimsel bilgiyi sunarak felsefenin gelişmesine, onda yeni alanların oluşmasına olanak tanırken (Kaygısız, 1997); eğitim felsefesi de, eğitimi engelleyen sorunları, eğitime yön veren kavram, düşünce ve ilkeleri açıklamaya çalışmaktadır (Ergün,2014). Bu araştırmada, eğitime yön veren felsefi akımlar, Yılmaz, Altınkurt ve Çokluk (2011) tarafindan geliştirilen “Eğitim İnançları Ölçeği”nde yer alan felsefi akımlar (ilerlemeci, Varoluş̧̧u Yeniden Kurmacı, Daimici, Esasici eğitim felsefeleri) çerçevesinde ele alınmış veaşağıda kısaca açıklanmaya çalışılmıştı:

Daimiciliğe göre eğitim, sağlam ve doğru karakterli insan tipi yetiştirmelidir. Değişmeyen evrensel ve entelektüel bir eğitim ile zeka düzeyi üstün, seçkin insan yetiştirmek bu yaklaşımın eğitsel hedefidir. insan doğasının evrenselliği edebiyat, tarih ve felsefede görülür. Bu nedenle, eğitim programlarının merkezinde beşeri bilimler olmalıdır (Fidan, Erden, 1987). Taşıdığı temel karakterlerle insan doğası evrenseldir. İnsan doğası gibi eğitimin de temel hedefleri zamana bağı olmayıp, evrensel niteliktedir. İnsanı tanımlayan en karakteristik niteliği rasyonelliği olup, eğitimin görevi de bu niteliği geliştirmektir. İnsan ırkını var eden aklın kanıtları ise bazı klasik yapıtlardır (Gutek, 2001).

Muhafazakar bir eğitim felsefesi akımı olan, realist ve idealist felsefenin izlerini taşıyan esasicilik, dünyada en yaygın kabul gören ve en uzun süre uygulanan akımdır (Tozlu ve Yayla, 2006). Bu akım programlardan daha çok konular üzerinde durur. Bu akıma göre programlardaki temel konulara ve değerlere önem verilmelidir (Arslanoğlu, 2012). Eğitimin amacı, geçmişte öğrenilmiş bilgi, beceri ve tutumları yani toplumun kültürünü yeni kuşaklara aktarmaktı (Üredi, 2009; Başaran, 1977).

İlerlemecilik akımı pragmatik felsefeye dayanır ve onun eğitime uygulanması olarak kabul edilir. Pragmatistlerin "geçeğin özü değişmedir" görüşünü esas alarak, eğitimin devamlı gelişme içinde olduğu anlayışını benimsemektedir (Cevizci, 1999; Toprakçı, 2005). Daimiciliğin karşısında yer alarak (Cevizci, 1999) geleneksel ve klasik eğitim anlayışını, oluşturulmuş kültürü genç jenerasyona devretmeye çalıştğından eleştirmektedir (Reedy, 2007; Akt, Yılmaz, 2015). Eğitimin amacı, toplumda geçmişten beri var olan değişmez, mutlak bilgileri yeni nesillere aktarmak değil, dünyanın sürekli değişen kavramları hakkında nasıl bilgi sahibi olunacağını öğretmektir (Ergün, 2009). Öğrencilerin konu hakkında ne düşüneceği değil, nasıl düşüneceği önemlidir. Bu yüzden, olay ve olgular öğrenciye sunulmalı, onlara sorular sorulmalı, çözüm yollarını düşünmeleri ve yargıda bulunmaları için firsat tanınmalıdır (Terzi, 2010).

Yeniden Kurmacılık akımı, toplumda yeni bir düzen sağlama görevinin okula ait olduğunu vurgulamaktadır (Kaygısız, 1997). Yeniden kurmacılık akımında eğitim, kültürü yeniden şekillendirme misyonuna sahiptir. Eğer problem çözme, yapısalcı düşünme, grup dinamizmi ve grup konsensüsü sağlanırsa, fiziki ve sosyal yapılar ve davranışların değişebileceğine inanılmaktadır (Uhie ve Osuji, 2006; Akt. Yılmaz, 2015). Yeniden kurmacılara göre, mutlak doğru yoktur ve toplum sürekli değişmektedir. Eğitim programları da zamanla değişecektir. Öğrencilere sunulacak bilgi de kesin değil, her an değişecek nitelikte olmalıdır (Kıncal, 2006). Bu akıma göre eğitim yalnız bugünkü yaşam değil, gelecektir. Olay ve olguların gelecek ile bağlantısı kurulmalıdır (Türkoğlu, 1997).

Varoluşçuların özgürlük anlayışı, bireyin karşısına sonsuz denecek kadar çok seçenek çıkarmak, bu seçeneklerin içinden bireyin istediğini seçebilmesidir. Bu aynı zamanda düşünmeyi, akıl yürütmeyi ve sorumluluğu gerektirmektedir (Turgut, 1991). Bu eğitim anlayışında en yüksek amaç, öğrenciyi kendisine döndürmek; varoluşunun sorumluluğunu üzerine almasını ve bir kişisel kimlik bilinci kazanarak kaderinin belirleyicisi olmasını sağlamaktır (Cevizci, 2015)

Bütün eğitimciler farkında olarak ya da olmayarak belirli bir eğitim felsefesine sahiptir. Dolayısıyla öğretmenlerin farklı eğitim felsefelerine olan yakınlıkları ya da uzaklıkları, işlevsel bir şekilde, öğrencilerin nasıl eğitileceğini etkile| Kastamonu Eğitim Dergisi, 27(6), 2019| 
mektedir (Yılmaz, Altınkurt ve Çokluk 2011). Öğretmenler her ne kadar hizmet öncesi eğitimlerinde bir felsefi akım çerçevesinde eğitilmeseler de; aldıkları eğitimin bütüncül bir sonucu olarak, eğitimle ilgili bazı temel görüş ve inanışlar geliştirmektedirler. Bu görüş ve inanışların oluşmasında, öğretmenin aldığı eğitimle birlikte, onun yaşama ve olaylara bakış açısı, içinde yaşadığı ev ve okul ortamı gibi faktörlerin de etkisi vardır. Öğretmenin eğitim hakkındaki bu görüş ve inanışları öğrencilere sundukları eğitimin niteliğinin de önemli bir belirleyicisidir (Doğanay ve Sarı, 2003). Özellikle bireyin inançları, bütüncül bir yapı oluşturarak belirli şekilde davranma eğilimi olarak davranışlarına yansımakta ve tutumlara etki etmektedir (Deryakulu, 2004). Tutum, kişiye özgü olan ve onun bir psikolojik objeyle ilgili düşünce, duygu, inanç ve davranışlarını düzenli biçimde oluşturan bir eğilimdir (Kağıtçıbaşı, 1999). Demokratik tutum ise, "bireyi belli insanlar, nesneler ve durumlar karşısında, demokrasi ilkeleri doğrultusunda belli davranışlar göstermeye iten öğrenilmiş eğilimlerdir (Gömleksiz, 1994). Demokratik yaşam kültürünü ve demokratik değerleri kazandırma görevi, okulun ve eğitim programlarının temel görevleri arasındadır (Davis, 2003; Blair, 2003; Akbaşlı, Yanpar-Yelken ve Sünbül, 2010). Demokratik tutum ve davranışları kazanmada öğrenciler, öğretmenin sınıf içindeki sözlerinden çok, onun sınıfta ne derece demokratik, hoşgörülü ve eşit davrandığından etkilenmektedir (Gordon, 1998, akt Tahiroğlu, 2014). Bu nedenle, öğretmenlerin temel görevlerinden biri sınıflarında demokrasiyi uygulamak ve öğrenciler için pozitif bir eğitim süreci yaratmaktır (Karatekin, Merey ve Kuş, 2013).

Alan yazın incelendiğinde öğretmen ya da öğretmen adaylarının eğitim inançlarını çeşitli değişkenler açısından açıklayan araştırmalara rastlamak mümkündür (Altınkurt, Yılmaz ve Oğuz, 2012; Doğanay ve Sarı, 2003; Kaya, 2007; Meral, 2014; Aslan, 2014, 2017; Aybek ve Aslan, 2017; Baş, 2015; Beytekin ve Kadı, 2015; Biçer, Er ve Özel, 2013; Bilgin, 2007; Çalışkan, 2013; Çetin, İlhan ve Arslan, 2012; Doğanay, 2011; Yılmaz, Altınkurt ve Çokluk, 2011; Ekiz, 2007; Görmez, 2015; Kumral, 2015; Özüdoğru, 2010; Yazıcı, 2017; Yokuş, 2016; Yılmaz ve Tosun, 2013). Ancak, öğretmen adaylarının eğitim felsefesi inançlarının öğretmenlik programına göre karşılaştrıldığı ve eğitim felsefesi inançları ve demokratik tutum arasındaki ilişkiyi inceleyen bir çalışmaya rastlanmamıştır. Bu nedenle araştırmada, öğretmen adaylarının eğitim felsefesi inançlarının incelenerek bazı değişkenlere göre karşılaştrııması ve eğitim felsefesi inançları ve demokratik tutumları arasındaki ilişkiyi ortaya koymak amaçlanmıştır. Bu amaç çerçevesinde aşağıdaki sorulara yanıtlar aranacaktır:

\section{Öğretmen adaylarının eğitim felsefesi inançlarına katılım düzeyi nedir?}

1. Öğretmen adaylarının eğitim inançları cinsiyetlerine göre farklılaşmakta mıdır?

2. Öğretmen adaylarının eğitim inançları devam ettikleri öğretmenlik programına göre (eğitim fakültesi/pedagojik formasyon sertifika programı) farklılaşmakta mıdır?

3. Öğretmen adaylarının tercih ettikleri eğitim felsefeleri ile demokratik tutumları arasında nasıl bir ilişki vardır?

\section{Yöntem}

\section{Araştırma Modeli}

Araştırmada ilişkisel tarama modeli esas alınmıştır. Bu modelde iki ya da daha çok değişken arasındaki birlikte değişim varlığı ve derecesini belirlemek amaçlanmaktadır. iliş̧isel araştırmalarda iki farklı ilişki çözümlemesi yapılabilir. Bunlar, korelasyon türü ilişki ve karşılaştırma yolu ile ede edilen ilişkilerdir (Karasar, 2006). Bu araştırmada öğretmen adaylarının tercih ettikleri eğitim felsefeleri betimlenmiş; öğretmen adaylarının eğitim felsefesi tercihleri cinsiyet ve öğretmenlik programına göre karşılaştırılarak anlamlılık ilişkileri incelenmiş ve eğitim felsefesi tercihleri ile demokratik tutumları arasındaki ilişkiyi belirlemek için de korelasyon hesaplamaları yapılmıştı.

\section{Çalışma Grubu:}

Araştırmanın çalışma grubunu, 2017-2018 öğretim yılında Necmettin Erbakan Üniversitesi Ahmet Keleşoğlu Eğitim Fakültesinde öğrenim görmekte olan ve pedagojik formasyon programına devam eden öğretmen adaylarından oluşmaktadır. Katılımcıların özellikleri Tablo 1 de verilmiştir.

Tablo 1. Öğretmen Adaylarının Demografik Özellikleri

\begin{tabular}{lllll}
\hline & & $f$ & $\%$ & Toplam \\
\hline Cinsiyet & Kadın & 187 & 71,1 & 263 \\
\hline \multirow{3}{*}{ Program Türü } & Erkek & 76 & 28,9 & \\
& Eğitim Fakültesinde öğrenim gören & 141 & 53,6 & 263 \\
& Pedagojik formasyon programına dahil olan & 122 & 46,4 & \\
\hline
\end{tabular}


Çalışma grubundaki öğretmen adaylarının \%71,1'i kadın ( $n=187), \% 28,9^{\prime}$ u erkektir ( $\left.n=76\right)$. Öğretmen adaylarının $\% 53,6$ 'sı eğitim fakültesinde öğrenim görmekte ( $n=141), \% 46,4$ 'ü ise pedagojik formasyon programına devam etmektedir $(n=122)$.

\section{Veri Toplama Araçları:}

\section{Demokratik Tutum Ölçeği:}

Öğretmenlerin demokratik tutumlarını belirlemek amacıyla Gözütok (1995) tarafından geliştirilen "Demokratik Tutum Ölçeği" kullanılmıştr. Ölçek, "Published for the Attitude Research Laboratory" tarafindan geliştirilen "Teacher Opinionaire on Democracy" ölçeğinin $\mathrm{G}$ ve $\mathrm{H}$ formlarının Türkçeye uyarlanması ile elde edilmiş olup, güvenirlik katsayısı 0,87 olarak hesaplanmıştr. 32 'si olumlu ve 18 'i olumsuz olmak üzere toplam 50 maddeden oluşan ölçeğe ,"Katilıyorum" veya "Katılmıyorum" şeklinde yanıt verilmektedir. Olumlu ifadelerde "Kathlıyorum" seçeneği 1, "Katılmıyorum" seçeneği 0; olumsuz ifadelerde ise tersi puanlama yapılmıştır. Ölçekten alınabilecek puanlar 0-50 arasında değişmektedir. Puanların yüksek olması, demokratik tutumun olumlu olduğunu göstermektedir (Gözütok, 1995).

\section{Eğitim İnançları Ölçeği:}

Öğretmen adaylarının eğitim inançlarının belirlenmesinde Yılmaz, Altınkurt ve Çokluk (2011) tarafından geliştirilen "Eğitim Inançları Ölçeği" kullanılmıştır. 40 maddeden oluşan ölçeğin alt boyutları, ilerlemecilik, Varoluşçuluk, Yeniden Kurmacılık, Daimicilik ve Esasicilik'dir. Maddeler "1-Kesinlikle Katımıyorum ve 5-Kesinlikle Katılıyorum şeklinde puanlanmaktadır. Alt ölçeklere ait madde sayısı farklı olduğu için, her bir alt ölçekten alınan puanın, alt ölçeğe ait madde sayısına bölünmesi ile 1 ile 5 arası bir ortalamaya dönüştürülmesi gerekmektedir. Alt ölçeklerden alınan puana göre, söz konusu eğitim felsefesi inancının ne ölçüde benimsendiğine karar verilmektedir. Ölçeğin Cronbach's Alfa katsayıları alt ölçeklerde 0.69-0.86 arasında olduğu bulunmuştur (Yılmaz ve diğ., 2011)

\section{Verilerin analizi:}

Yapılan çalışmada, öğretmen adaylarının eğitim felsefesi inançlarını belirlemek amacıyla betimsel istatistikler kullanılmıştır. Analizlere başlamadan önce, öğretmen adaylarının ölçeklere verdikleri yanıtların normallik varsayımlarını karşılayıp karşılamadığı kontrol edilmiş; normallik varsayımlarını karşılamadığından verilerin analizinde nonparametrik testler kullanılmıştır. Öğretmen adaylarının eğitim felsefesi inançlarının cinsiyet ve öğretmenlik programına göre karşılaştırımasında Mann Whitney U testi, eğitim felsefesi tercihleri ile demokratik tutumları arasındaki ilişkinin belirlenmesinde ise Spearman Sıra Farkları Korelasyon Katsayısı kullanılmıştır.

\section{Bulgular}

Araştırmanın bu bölümünde, ilk olarak öğretmen adaylarının tercih ettikleri eğitim felsefesi inançlarına ilişkin betimsel istatistikler sunulmuş, daha sonra öğretmen adaylarının eğitim felsefesi inançları cinsiyet ve öğretmenlik programı değişkenine göre karşılaştırımış; son olarak eğitim felsefesi inançları ile demokratik tutumları arasındaki ilişkiye ilişkin bulgular verilmiştir.

Tablo 2. Öğretmen Adaylarının Tercih Ettikleri Eğitim Felsefelerine ilişkin Betimsel İstatistikler

\begin{tabular}{lccccc}
\hline & K (Madde sayısı) & En Düşük Puan & En Yüksek Puan & X/K & S \\
\hline ilerlemecilik & 13 & 1,23 & 5,00 & 4,25 &, 55 \\
Varoluşçu eğitim & 7 & 1,00 & 5,00 & 4,42 &, 59 \\
Yeniden kurmacılık & 7 & 1,29 & 5,00 & 3,92 &, 68 \\
Daimicilik & 8 & 1,00 & 5,00 & 4,03 &, 59 \\
Esasicilik & 5 & 1,00 & 5,00 & 2,72 &, 75 \\
\hline
\end{tabular}

Tablo 2' ye göre, öğretmen adaylarının tercih ettikleri eğitim felsefeleri incelendiğinde, en yüksek ortalamanın varoluşçu eğitim felsefelerine ilişkin ortalama puanlarına ait olduğu görülmektedir ( $X / K=4,42)$. Tercih edilen eğitim felsefeleri sırası ile varoluşçu eğitim $(X / K=4,42)$, ilerlemecilik $(X / K=4,25)$, daimicilik $(X / K=4,03)$, yeniden kurmacılık $(X /$ $K=3,92)$, esasicilik $(X / K=2,72)$ şeklindedir. Bu bulgular öğretmen adaylarının daha çok varoluşçu ve ilerlemeci eğitim felsefesini benimserken; esasicilik eğitim felsefesini daha az benimsediklerini göstermektedir.

Öğretmen adaylarının eğitim felsefelerinin cinsiyetlerine göre farklılaşıp farklılaşmadığını belirlemek için yapılan Mann Whitney U testi sonuçları Tablo 3 de verilmiştir. 
Tablo 3. Öğretmen Adaylarının Tercih Ettikleri Eğitim Felsefelerinin Cinsiyetlerine Göre Karşılaştırılması

\begin{tabular}{lcccccc}
\hline & Cinsiyet & N & Sıra Ortalaması & Sıra Toplamı & U & P \\
\hline \multirow{2}{*}{ ilerlemecilik } & Kadın & 187 & 131,20 & 24533,50 & 6955,500 & .787 \\
& Erkek & 76 & 133,98 & 10182,50 & & \\
Varoluşçuluk & Kadın & 187 & 133,67 & 24995,50 & 6794,500 & .575 \\
& Erkek & 76 & 127,90 & 9720,50 & & \\
Yeniden Kurmacılık & Kadın & 187 & 130,12 & 24332,50 & 6754,500 & .529 \\
& Erkek & 76 & 136,63 & 10383,50 & & \\
Daimicilik & Kadın & 187 & 124,81 & 23340,00 & 5762,000 & .016 \\
& Erkek & 76 & 149,68 & 11376,00 & & \\
Esasicilik & Kadın & 187 & 128,13 & 23960,00 & 6382,000 & .194 \\
& Erkek & 76 & 141,53 & 10756,00 & & \\
\hline
\end{tabular}

Tablo 3 incelendiğinde öğretmen adaylarının eğitim felsefeleri, diğer alt boyutlarında cinsiyete göre anlamlı bir farklılık göstermezken, daimicilik alt boyutunda $(U=5762,000 ; p<.05)$ cinsiyete göre anlamlı düzeyde farklılaşmaktadır. Sıra ortalamaları dikkate alındığında erkek öğretmen adaylarının kadın öğretmen adaylarına göre daimici eğitim felsefesini daha fazla benimsedikleri söylenebilir.

Araştırmanın diğer alt problemi, öğretmen adaylarının eğitim felsefelerinin devam ettikleri öğretmenlik programına göre farklılaşıp farklılaşmadığını belirlemektir. Bu amaçla yapılan Mann Whitney U testi sonuçları Tablo 4 de verilmiştir.

Tablo 4. Öğretmen Adaylarının Tercih Ettikleri Eğitim Felsefelerinin Öğretmenlik Programına Göre Karşılaştrııması

\begin{tabular}{|c|c|c|c|c|c|c|}
\hline & Öğretmenlik programı & $\mathrm{N}$ & Sıra Ortalaması & Sıra Toplamı & $U$ & $P$ \\
\hline \multirow{2}{*}{ Illerlemecilik } & Eğitim Fak. & 141 & 113,89 & 16058,00 & 6047,000 & 000 \\
\hline & Formasyon & 122 & 152,93 & 18658,00 & & \\
\hline \multirow{2}{*}{ Varoluşçuluk } & Eğitim Fak. & 141 & 121,82 & 17176,00 & 7165,000 & 019 \\
\hline & Formasyon & 122 & 143,77 & 17540,00 & & \\
\hline \multirow{2}{*}{$\begin{array}{l}\text { Yeniden } \\
\text { kurmacılık }\end{array}$} & Eğitim Fak. & 141 & 112,72 & 15894,00 & 5883,000 & ,000 \\
\hline & Formasyon & 122 & 154,28 & 18822,00 & & \\
\hline \multirow{2}{*}{ Daimicilik } & Eğitim Fak. & 141 & 111,92 & 15781,00 & 5770,000 & ,000 \\
\hline & Formasyon & 122 & 155,20 & 18935,00 & & \\
\hline \multirow{2}{*}{ Esasicilik } & Eğitim Fak. & 141 & 153,75 & 21679,00 & 5534,000 & ,000 \\
\hline & Formasyon & 122 & 106,86 & 13037,00 & & \\
\hline
\end{tabular}

Tablo 4'de görüldüğü gibi, öğretmen adaylarının eğitim felsefeleri, devam ettikleri öğretmenlik programı değişkenine göre tüm alt boyutlarda farklılaşmaktadır. Öğretmen adaylarının ilerlemeci eğitim felsefesi inançları $(U=6047,000$; $p<.05)$; varoluşçu eğitim felsefesi inançları $(U=7165,000 ; p<.05)$; yeniden kurmacı eğitim felsefesi inançları $(U=5883,000$; $p<.05)$; daimici eğitim felsefesi inançları $(U=5770,000 ; p<.05)$ ve esasici eğitim felsefesi inançları $(U=5534,000 ; p<.05)$ öğretmenlik programına göre anlamlı düzeyde farklılaşmaktadır. Sıra ortalamaları dikkate alındığında pedagojik formasyon eğitimi alan öğretmen adaylarının eğitim fakültesinde öğrenim göre öğretmen adaylarına göre ilerlemeci, varoluşçu, yeniden kurmacı ve daimici eğitim felsefelerine daha yakın oldukları söylenebilir. Eğitim fakültesinde öğrenim görmekte olan öğretmen adayları formasyon eğitimi alan öğretmen adaylarına göre esasici eğitim felsefesini daha fazla benimsemektedir.

Araştırmanın diğer amacı, öğretmen adaylarının eğitim felsefesi inançları ile demokratik tutumları arasındaki ilişkiyi betimlemektir. Tablo 5'de eğitim felsefesi inançları ile demokratik tutumları arasındaki ilişkiyi açıklayan korelasyon matrisi yer almaktadır.

Tablo 5. Eğitim Felsefesi İnançları ile Demokratik Tutumlarına İlişkin Korelasyon Matrisi

\begin{tabular}{llllll}
\hline & Ilerlemecilik & Varoluşçu eğitim & Yeniden kurmacılık & Daimicilik & Esasicilik \\
\hline Demokratik Tutum & ,082 &, $147^{*}$ &, 063 &,- 033 &,$- 149^{*}$ \\
&, 185 &, 017 &, 309 &, 599 &, 016 \\
\hline
\end{tabular}


Tablo incelendiğinde, öğretmen adaylarının varoluşçu eğitim felsefesi inançları ile demokratik tutumları arasında $(r=.147, p<0,05)$ pozitif yönde düşük düzeyde bir ilişkinin olduğu görülmüştür. Aynı zamanda, öğretmen adaylarının esasici eğitim felsefesi inançları ile demokratik tutumları arasında $(r=-.149, p<0,05)$ negatif yönde düşük düzeyde bir ilişki olduğu tespit edilmiştir. Öğretmen adaylarının ilerlemeci $(r=.082)$, yeniden kurmacı $(r=.063)$ ve daimici $(r=-.033)$ eğitim felsefesi inançları ile demokratik tutumları arasında anlamlı bir ilişkinin olmadığı görülmektedir.

\section{Sonuçlar ve Öneriler}

Bu araştırmada, öğretmen adaylarının eğitim felsefesi inançlarının incelenerek bazı değişkenlere göre karşılaştırıması ve eğitim felsefesi inançları ve demokratik tutumları arasındaki ilişkiyi ortaya koymak amaçlanmıştr. Bu amaçla ilk olarak, öğretmen adaylarııı tercih ettikleri eğitim felsefelerinin genel görünümü belirlenmiştir. Öğretmen adaylarının tercih ettikleri eğitim felsefeleri sırasıyla varoluş̧̧uluk, ilerlemecilik, daimicilik, yeniden kurmacılık, esasiciliktir. Öğretmen adayları tarafindan en çok tercih edilen varoluş̧̧uluk, genel olarak insanı ön plana çıkararak, bireylere özgürlük kazandıracak bir eğitim anlayışını benimser ve öğrencilerin kendi öğrenmelerinden sorumlu bağımsız öğrenenler olarak yetiştirilmesini hedefler. Çocuğun kendi bireyselliğini geliştirmeye imkan sağlaması açısından önemlidir (Ersözlü, 2009). Bu anlayışta öğretmen, kopya kişiler yetiştirmeye çalışmaz. Öğrencinin doğru, iyi ve güzelle ilgili olarak kendi inancını geliştirmesi gerekir. Bunun için öğrenci, insani bilimleri merkeze alan ve öğrencinin varlığını bir bütün olarak gören bir ortam içinde yetiştirilmelidir (Büyükkaragöz ve vd, 1977). Öğretmen adayları ikinci sırada ilerlemecilik felsefesini tercih etmiştir. İlerlemeci eğitim felsefesinde ise eğitimin amacı, öğrencileri değişen dünyanın koşullarına aktif bir şekilde hazırlamaktır (Tuncel, 2004). Öğretmen adaylarının en çok benimsediği her iki felsefe de öğrenci merkezlidir. Bu durumda, öğretmen adaylarının, öğrenci merkezli bakış açısına sahip olan, bireysel farklılıkları dikkate alan, bireysel özgürlüğe değer veren, kendilerini öğrenmenin kolaylaştrıcısı olarak gören, rehberlik eden, anlatmaktan çok dinleyen, motive eden, merak edici bir çevre yaratan, yaparak yaşayarak öğrenme firsatı sağlayan bir eğitim anlayışını savundukları söylenebilir. Öğretmen adaylarının öğrenci merkezli eğitimi daha fazla tercih etmiş olmaları, öğretmenlik eğitimlerinde, öğrenci merkezli eğitime ve önemine sıklıkla vurgu yapılmasından kaynaklanıyor olabilir. Geleceğin öğretmeni konumunda olan öğretmen adaylarının öğrenci merkezli eğitime olan inançlarının, gelecek uygulamaları şekillendireceği düşünüldüğünde bu bulgu, oldukça sevindiricidir. Ancak, , Şişman ve Turan (2004)'a göre Türk eğitim sistemi geleneksel ve öğretmen merkezli bir görünümdedir ve uygulamalar öğretmenlerin geleneksel eğitim felsefelerini daha fazla işe koştukları şeklindedir (Çiftçi, Sünbül ve Köksal, 2013; Yelken, Üredi, Tanrıseven ve Kılıç, 2010).

Öğretmen adayları tarafindan tercih edilen eğitim felsefeleri alanyazındaki benzer araştırma sonuçları ile de paralellik göstermektedir. İlgili literatür incelendiğinde, Altınkurt, Yılmaz ve Oğuz (2012), Tunca, Alkın-Şahin ve Oğuz (2015), Yılmaz ve Tosun (2013), Aslan (2017), Ekiz (2007) öğretmenlerin; Yazıcı (2017) ise, öğretmen adaylarının en çok tercih ettikleri eğitim inançlarını varoluşçuluk ve ilerlemecilik olarak belirtmişlerdir. Biçer, Er ve Özer (2013) öğretmen adaylarının en çok ilerlemecilik ve daimicilik felsefesini benimsediğini belirtmiştir. Duman (2008), Doğanay ve Sarı (2003), Çalışkan (2013) ve Görmez (2015)'in araştırma sonuçlarına göre öğretmen adayları ilk sırada ilerlemeci eğitim felsefesini benimsemektedir.; Aybek ve Aslan (2017) tarafindan yapılan araştırmada ise öğretmen adaylarının çağdaş eğitim felsefelerini daha fazla benimsediği sonucuna ulaşımıştır. Çetin, Illhan ve Arslan (2012)'ın araştırmasında farklı sonuçlara ulaşılmıştr; araştırma sonuçlarına göre, öğretmen adayları daha çok daimicilik ve esasicilik felsefesini benimsemektedir.

Araştırmanın bir diğer bulgusuna göre, öğretmen adaylarının eğitim felsefeleri Daimicilik alt boyutunda cinsiyete göre erkek öğretmen adayları lehine anlamlı bir farklılık göstermektedir. Araştırmaya ait bu bulgu, alanyazındaki bazı çalışma sonuçlarıyla paralellik göstermektedir. Yılmaz ve Tosun (2013)'un araştırma sonuçlarına göre, Daimici ve Esasici eğitim felsefelerine erkek öğretmenler daha yüksek katılım gösterirken, Varoluş̧̧u eğitim felsefesine kadın öğretmenler daha yüksek kathlım göstermiştir. Kumral (2015)'ın araştırmasında erkekler lehine geleneksel eğitim felsefesi puanlarında anlamlı farklar olduğu görülmüştür. . Aslan (2017) araştırmasında, ilerlemecilik ve varoluşçu eğitim felsefelerinde kadınlar lehine; Beytekin ve Kadı (2015), ilerlemecilik ve varoluşçuluk, yeniden kurmacılık alt boyutlarında kadınlar lehine; Yazıcı (2017), esasicilik alt boyutunda erkekler lehine anlamlı bir fark bulmuşlardır. Araştırma bulguları ve ilgili literatüre ait bulgulardan hareketle kadın öğretmen adaylarının daha çok çağdaş eğitim felsefelerini tercih ederken, erkek öğretmen adaylarının geleneksel felsefeleri daha fazla tercih ettikleri söylenebilir. Ancak yapılan bazı çalışmalarda öğretmen ya da öğretmen adaylarının eğitim felsefesi alt boyutlarında cinsiyete göre anlamlı bir fark bulunmamıştı (Altınkurt, Yılmaz ve Oğuz, 2012; Çetin, ilhan ve Arslan, 2012; Uğurlu, Çalmaşur, 2017; Doğanay ve Sarı 2003; Kaya, 2007; Görmez, 2015; Biçer, Er ve Özel, 2013; Yokuş, 2016).

Öğretmen adaylarının tercih ettikleri eğitim felsefeleri öğretmenlik programlarına göre tüm alt boyutlarda farklılaşmaktadır. Sıra ortalamaları dikkate alındığında pedagojik formasyon eğitimi alan öğretmen adaylarının eğitim fakültesinde öğrenim gören öğretmen adaylarına göre ilerlemeci, varoluşçu, yeniden Kurmacı ve daimici eğitim felsefelerine 
daha yakın oldukları söylenebilir. Bu durum pedagojik formasyon eğitimi alan öğretmen adaylarının çağdaş eğitim felsefelerini daha fazla benimsemiş olmaları, öğretim uygulamalarında eğitim fakültesinde öğrenim görmekte olan öğretmen adaylarına göre daha fazla öğrenci merkezli bir bakış açısına sahip oldukları şeklinde yorumlanabilir. Araştırmaya ait bu bulgu, alanyazındaki bazı araştırma sonuçları ile benzerlik göstermektedir. Kumral (2015), pedagojik formasyon sertifika programı öğrencileri üzerinde yürüttüğü araştırmasında, öğretmen adaylarııı popüler eğitim felsefesi maddelerinden daha fazla aritmetik ortalamaya sahip olduğunu bulmuştur. Bir diğer sonuca göre, pedagojik formasyon programına devam eden öğretmen adayları, eğitim fakültesinde öğrenim gören öğretmen adaylarına göre, daimici eğitim felsefesini daha fazla benimsemektedir. Bunun nedeni, pedagojik formasyon eğitimi alan öğretmen adaylarının öğrenim gördükleri lisans eğitiminin doğasından kaynaklanıyor olabilir. Bu çalışmaya katılan pedagojik formasyon eğitimi alan öğretmen adaylarının büyük çoğunluğu Edebiyat, Tarih, Matematik, Adalet gibi bölümlerde öğrenim görmekte ya da mezun konumundadır. Bir diğer bulguya göre, eğitim fakültesinde öğrenim görmekte olan öğretmen adayları pedagojik formasyon eğitimi alan öğretmen adaylarına göre esasicilik eğitim felsefesini daha fazla benimsemektedir. Eğitim fakültesinde öğrenim görmekte olan öğretmen adaylarının esasici eğitim felsefesini daha fazla benimsemiş olmaları, onların öğrenme ortamlarına ilişkin yaşantılarından kaynaklanıyor olabilir. Esasi eğitimin amacı, genel refahı ve sosyal birliği güvence altnna almak için kültürel aktarımı gerçekleştirmektir (Tuncel, 2004). Esasiciler, ilerlemecileri öğrenciye verdikleri serbestlik ve öğrencilere göre program düzenleme düşüncelerinden dolayı eleştirirler. Eğitim sürecinin özünü, konu alanının çok iyi özümlenmesi oluşturur. Okulun eğitim görebi, entelektüel ve ahlaki disiplinler yoluyla kültürün özünü korumak ve devamlılı̆ını sağlamaktır (Arslanoğlu, 2012). Araştırmaya ait bu bulguyu genel anlamda değerlendirdiğimizde, pedagojik formasyon eğitimi alan öğretmen adaylarının çağdaş eğitim felsefelerini daha fazla benimsemektedir ve öğretmenlik programına göre eğitim felsefesi alt boyutlarında görülen farklılığa ilişkin bu sonuç oldukça düşündürücüdür. Bu farklıı̆̆ın nedeni, pedagojik formasyon eğitimi alan öğretmen adaylarının farklı öğrenme ortamlarından gelmeleri, pedagojik formasyon eğitimi veren öğretim elemanlarının sağladığı öğrenme ortamlarındaki bazı farklııklar ya da yetişmiş oldukları aile/toplumun etkisi olarak söylenebilir. Öğretmen adaylarının felsefi tercihlerine dayalı bu farklıı̆ın nedenini belirlemeye yönelik daha kapsamlı çalışmalar yapılması bu farklılığın nedenine dair fikir edinmemizi sağlayabilir.

Araştırmanın bir diğer sonucuna göre, öğretmen adaylarının eğitim felsefeleri ile demokratik tutumları arasında anlamlı ilişkiler bulunmuştur. Öğretmen adaylarının varoluş̧̧u eğitim felsefesi inançları ile demokratik tutumları arasında $(r=.147, p<0,05)$ pozitif yönde düşük düzeyde bir ilişkinin olduğu görülmüştür. Aynı zamanda, öğretmen adaylarının esasici eğitim felsefesi inançları ile demokratik tutumları arasında $(r=-.149, p<0,05)$ negatif yönde düşük düzeyde bir ilişki olduğu tespit edilmiştir. Öğretmen adaylarının ilerlemeci $(r=.082)$, yeniden kurmacı $(r=.063)$ ve daimici $(r=-.033)$ eğitim felsefesi inançları ile demokratik tutumları arasında anlamlı bir ilişkinin olmadığı görülmektedir. Bu bulgulara göre, öğretmen adaylarının varoluşçu eğitim felsefesi inançları yükseldikçe demokratik tutumları da yükselmekte; esasici eğitim felsefesi inançları yükseldikçe demokratik tutum puanları düşmektedir. Başka bir ifade ile, öğretimde öğrenciye değişik seçenekler sunarak, doğruyu bulma ve kendi gerçeklerini seçme firsatı sunmaya olan inanç arttkça, haklara saygı, kişiliğe saygı, adalet, sorumluluk, eşitlik, hoşgörü, işbirliği yönündeki olumlu tutum da artmakta; eğitimde öğretmen merkezli eğitime verilen önem ve disipline olan inanç artthkça; demokratik tutum puanları azalmaktadır. Alan yazın incelendiğinde, öğretmen adaylarının eğitim felsefelerinin çeşitli değişkenler açısından incelendiği araştırmalara rastlanmakla birlikte; eğitim felsefeleri ve demokratik tutumları arasındaki ilişkiyi araştıran bir çalışmaya rastlanmamıştır. Araştırmamızda aynı kavramsal çerçevede bulunmasa da Oğuz (2011)'un çalışması bütüncül olarak değerlendirildiğinde araştırma bulgularımıza ışık tutacak niteliktedir. Oğuz (2011) araştırmasında, öğretmen adaylarının yapılandırmacı anlayışa ilişkin inançları arttıç̧a, eğitim hakkı, dayanışma ve özgürlük boyutlarındaki değerlerinin de yükseldiğini bulmuştur. Varoluşçu filozoflara göre insan, özgür olan, seçim yapabilen, karar verebilen, kendi varlığı üzerinde düşünebilen, varlığının anlamını sorgulayabilen tek varlıktır; (Topses, 2012) ve insanın bireyselliğini, kendine özgülüğünü hiçe sayan, onu bir nesne olarak algılayan tüm yaklaşımları reddeder (Sönmez, 2005). Eğitimin en önemli amacı da bireye insan özgürlüğünün, herşeyden üstün olduğunu öğreterek kendi bireyselliğini geliştirmeye ve kendini gerçekleştirmesine olanak verilmesidir (Sönmez, 2005). Bayrakdar (2016)'a göre, günümüzde sıkça gündeme getirilen öğrenci merkezli eğitim, eğitimin bireyselleştirilmesi, eğitim sürecinde bireyin ilgi, ihtiyaç ve gelişim dönemi özelliklerinin dikkate alınması, öğrencinin eğitim sürecine aktif olarak katılması, eğitim ortamlarının demokratikleştirilmesi, özgürleştirici eğitim gibi söylemlerde Varoluşçu felsefenin etkisi vardır. Bu bağlamda, varoluşçu eğitim felsefesinin amacı ve etkisi açısından düşünüldüğünde, bireyin varoluş̧̧u felsefeye inancı arttkç̧a demokratik tutumun da artacağı beklenmektedir. Esasicilere göre eğitimin en önemli görevi, toplumun kültürünü, değerlerini geleceğe yansıtmaktr. Yeni kuşakların eskiler gibi davranması önemlidir. Toplumsal değerlerin birey üzerinde bir baskı aracı olarak kullanılması Varoluşçu felsefe ile bağdaşmaz. Bu noktada öğrencilerin toplumsal değerlerin farkına varmalarını, bilinçli bir şekilde bu değerlere yönelmelerini, onları anlamlandırmalarını, değerlendirmelerini ve özgür iradeleriyle kabullenmelerini ya da reddetmelerini sağlayacak eğitim ortamlarının hazırlanması oldukça önemlidir. Varoluşçu felsefe perspektifinden bakıldığında, öğrencilerin kendi- 
lerini rahat ve güvende hissedecekleri; duygularını, düşüncelerini özgür bir şekilde ifade edebilecekleri demokratik bir sınıf ortamı oluşturulmalıdır. Sınıfta disiplini sağlamanın, etkili / verimli bir öğretim için sadece bir araç olduğu, bir amaç olmadığı asla göz ardı edilmemeli; sınıfta düzen sağlama uğruna öğrencilerin özgürlüklerini kıııtlayıcı, onları baskı altına alıcı uygulamalara teşebbüs edilmemelidir (Bayrakdar, 2016).

Araşttrma bulgularına göre şu sonuçlar çıkarılabilir: 1. öğretmen adayları çağdaş eğitim felsefelerini geleneksel eğitim felsefelerine göre daha fazla tercih etmektedir. 2. Öğretmen adaylarının tercih ettikleri eğitim felsefeleri cinsiyetlerine göre daimicilik alt boyutunda erkek öğretmen adayları lehine anlamlı düzeyde farklılaşmaktadır. 3. Pedagojik formasyon programına devam eden öğretmen adayları, eğitim fakültelerinde öğrenim gören öğretmen adaylarına göre çağdaş eğitim felsefelerini daha fazla benimsemektedir. 4. Varoluşçu eğitim felsefesi inancı ile demokratik tutum arasında düşük düzeyde ve pozitif yönde; esasici eğitim felsefesi inancı ile demokratik tutum arasında düşük düzeyde ve negatif yönde anlamlı ilişkiler vardır.

Bu sonuçlara göre şu önerilerde bulunulabilir:

Öğretmen adaylarının öğrenim gördükleri program açısından benimsemiş oldukları eğitim felsefelerinin farklılaşmasına dair nitel çalışmaların yapılması, özellikle eğitim fakültesinde öğrenim gören öğretmen adaylarının eğitim inançlarının kaynaklarını belirlemek açısından yerinde olacaktır.

\section{Kaynakça}

Akbaşlı, S., Yanpar-Yelken, T. \& Sünbül, A.M. (2010). Öğretmen Adayı Demokratik Eğilim Ölçeği Geliştirme Çalışması. Uluslararası Avrasya Sosyal Bilimler Dergisi, 1 (1), 94-108

Altınkurt, Y., Yılmaz, K. \& Oğuz, A. (2012). İlköğretim ve Ortaöğretim Öğretmenlerinin Eğitim İnançları. Ondokuz Mayıs Üniversitesi Eğitim Fakültesi Dergisi, 31 (2), 1-19

Aslan, Ö.M. (2014). Eğitim Felsefesi Dersinin Okul Öncesi Öğretmen Adaylarının Felsefi Tercihlerine ve Eleştirel Pedagojiye Yönelik Olan Görüşlerine Etkisi. Elektronik Sosyal Bilimler Dergisi, 13 (48), 1-14

Aslan, S. (2017). Sınıf Öğretmenlerinin Eğitim İnançlarının Çeşitli Değişkenler Açısından İncelenmesi. Kastamonu Eğitim Dergisi, 25(4), 1453-1468

Arslanoğlu, i. (2012). Eğitim Felsefesi. Ankara: Nobel Yayınları

Aybek, B.\&Aslan, S. (2017). Öğretmen Adaylarının Eleştirel Düşünme Eğilimleri ile Benimsedikleri Eğitim Felsefelerinin Çeşitli Değişkenler Açısından Incelenmesi. Gaziantep University Journal of Social Sciences, 16 (2), 373-385.

Baş, G. (2015). Öğretmenlerin Eğitim Felsefesi İnançları ile Öğretme-Öğrenme Anlayışları Arasındaki İlişki. Eğitim ve Bilim, 40 (182), 111-126

Başaran, I.E. (1977). Eğitime Giriş. Ankara: Bilim Matbaası

Bayrakdar, N. (2016). Sınıf Disiplini Problemine Varoluşçu Felsefe Perspektifinden Genel Bir Bakış. Uluslararası Sosyal Araştırmalar Dergisi, 9(43), 1397-1404

Beytekin, O. F. \& Kadı,A. (2015). Öğretmen Adaylarının Eğitim İnançları ve Değerleri Üzerine Bir Çalışma. JASSS, 31 , $327-341$

Biçer, B., Er, H. \& Özel, A. (2013). Öğretmen Adaylarının Epistemolojik İnançları ve Benimsedikleri Eğitim Felsefeleri Arasındaki Ilişki. Eğitimde Kuram ve Uygulama, 9(3), 229-242

Bilgin, S. (2007). Branş Öğretmenlerinin Felsefi Yaklaşımlarına Dönük Bir Inceleme. Kafkas Üniversitesi, Sosyal Bilimler Enstitüsü, Yayınlanmamış Yüksek Lisans Tezi

Büyükkaragöz, S., Muşta, M.C., Yılmaz, H. ve Pilten, Ö. (1997). Eğitime Giriş. Konya: Günay Ofset

Cevizci A. (1999). Felsefe Sözlügü. İstanbul: Paradigma Yayınları

Cevizci, A. (2015). Eğitim Felsefesi. İstanbul: Say Yayınları

Çalışkan, M. (2018). Eğitimin Felsefi Temelleri. Eğitim Bilimine Giriş (Ed.: M. Yavuz). Ankara:Anı Yayınları

Çalışkan i. (2013). Fen Öğretmen Adaylarının Eğitim Felsefesi Yaklaşımları İle Planlama Süreçleri Üzerine Bir Çalışma. Hacettepe Üniversitesi Eğitim Fakültesi Dergisi, Özel Sayı (1), 68-83

Çetin, B., İlhan, M. \& Arslan, S. (2012). Öğretmen Adaylarının Benimsedikleri Eğitim Felsefelerinin Çeşitli Değişkenler Açısından Incelenmesi. The Journal of Academic Social Science Studies, 5(5), 149-170.

Çiftçi, S., Sünbül, A. M. \& Köksal, O. (2013). Sınıf Öğretmenlerinin Yapılandırmacı Yaklaşıma Göre Düzenlenmiş Mevcut Programa İlişsin Yaklaşımlarının ve Uygulamalarının Değerlendirilmesi. Mersin Üniversitesi Eğitim Fakültesi Dergisi, 9(1), $281-295$.

Demirel, Ö. (2003), Kuramdan Uygulamaya Eğitimde Program Geliştirme, Ankara: Pegem Akademi

Deryakulu, D. (2004). Epistemolojik inançlar. Kuzgun, Y. \& Deryakulu, D. (Eds.), Eğitimde Bireysel Farklılıklar (ss. 259-287). Ankara: Nobel Yayın Dağıtım

Doğanay, A. (2011). Hizmet Öncesi Öğretmen Eğitiminin Öğretmen Adaylarının Felsefi Bakış Açılarına Etkisi. Eğitim ve Bilim, 36 (161)

|Kastamonu Eğitim Dergisi, 27(6), 2019| 
Doğanay, A. \& Sarı, M. (2003). Ilköğretim Oğretmenlerinin Sahip Oldukları Eg̈itim Felsefelerine liş̧kin Algıların Değerlendirilmesi. Türk Eğitim Bilimleri Dergisi, 1(3), 321-337.

Duman, B. (2008). Öğrencilerin Benimsedikleri Eğitim Felsefeleriyle Kullanıldıkları Öğrenme Strateji ve Öğrenme Stillerinin Karşılaştırılması. Çukurova Üniversitesi Sosyal Bilimler Enstitüsü Dergisi, 17 (1), 203-224.

Ekiz, D. (2007). Öğretmen Adaylarının Eğitim Felsefesi Akımları Hakkında Görüşlerinin Farklı Programlar Açısından İncelenmesi. Ondokuz Mayıs Üniversitesi Eğitim Fakültesi Dergisi, 24, 1-12

Ergün, M. (2009). Eğitim Felsefesi (2. Baskı).Ankara: Pegem A Yayınları

Ersözlü, Z.N. (2009). Eğitimin Felsefi Temelleri. Eğitim Bilimine Giriş içinde. Gündüz Eğitim ve Yayıncılık

Ertürk, S. (1988). Türkiye'de Eğitim Felsefesi Sorunu. Hacettepe Üniversitesi Eğitim Fakültesi Dergisi, 3, 11-16

Fidan, N. ve Erden, M. (1998). Eğitim Bilimine Giriş. Ankara: Alkım Eğitim Yayınları

Gömleksiz, M. (1994). Türk Dili ve Edebiyat Dersinde Uygulanan Kubaşık Öğrenme Yönteminin Demokratik Tutumlara ve Benlik Saygısına Etkisi. I. Eğitim Bilimleri Kongresi Bildiri Kitabı. 476-493. Adana.

Görmez, S. (2015). Öğretmen Adaylarının ve Öğretmenlerin Eğitim Felsefelerinin Belirlenmesi ve Eğitim Ortamı Açısından incelenmesi. Gazi Üniversitesi, Eğitim Bilimleri Enstitüsü, Yayınlanmamış Yüksek Lisans Tezi

Gözütok, D. (1995). Öğretmenlerin Demokratik Tutumları, Ankara: Türk Demokrasi Vakfi Yayınları

Gutek, L. Gerald (2001). Eğitimde Felsefi ve Ideolojik Yaklaşımlar. Çev: N. Kale, Ankara: Ütopya Yayınevi

Güzey, C. (2000). Felsefe ve Eğitim. Felsefelogos Dergisi, Sayı, 10, Bulut Yayınevi, İstanbul

Helvacı, A. (2007). Eğitimin Felsefi Temelleri. Eğitim Bilimine Giriş (Ed: Ereş, F.), Ankara: Maya Akademi

Hesapçığlu, M. ve Akdağ, B. (2007). Eğitimin Felsefesi Temelleri. Eğitim Bilimine Giriş (Ed: Gürsel, M.,Hesapçığlu, M.), Konya: Eğitim Kitabevi

Kağıtçıbaşı, Ç. (1999). Yeni Insan ve Insanlar. İstanbul: Evrim Yayınevi

Karasar, N. (2006). Bilimsel Araştırma Yöntemi. Nobel Yayın Dağıtım: Ankara

Karatekin, K. Merey, Z. \& Kuş, Z. (2013). Öğretmen Adayları ve Öğretmenlerin Demokratik Tutumlarının Çeşitli Değişkenler Açısından İncelenmesi. Kastamonu Eğitim Dergisi, 21(2)

Kaya, S. (2007). İlk ve Orta Öğretim Okulu Yöneticilerinin Eğitim Felsefesi Akımlarına Karşı Eğilimlerinin Değerlendirilmesi. Yeditepe Üniversitesi, Sosyal Bilimler Enstitüsü, Yayınlanmamış Yüksek Lisans Tezi

Kaygısız, ì. (1997). Eğitim felsefesi ve Türk Eğitim Sisteminin Felsefi Temelleri. Erişim tarihi:10.02.2018http://felsefe.kku.edu.tr/belgeler/ders/egitim_felsefesi/egitim_felsefesi_akimlari.pdf.

Kıncal, R. Y. (2006). Eğitim Bilimine Giriş (1. Baskı). Ankara: Nobel Yayın Dağıtım

Kodan Çetinkaya, S. (2013). Üniversite Öğrencilerinin Şiddet Eğilimlerinin ve Toplumsal Cinsiyet Rollerine İlişkin Tutumlarının İncelenmesi. Nesne, 1 (2), 21-43.

Kumral, O (2015a). Öğretmen Adaylarının Eğitim Felsefeleri: Pamukkale Üniversitesi Eğitim Fakültesi Örneği. Hasan Ali Yücel Eğitim Fakültesi Dergisi, 1(2), 59-68

Kumral, O. (2015b). Pedagojik Formasyon Eğitimi Sertifika Programına Katılan Öğretmen Adaylarının Eğitim Felsefeleri. Eğitim ve Öğretim Araştırmaları Dergisi, 4(2), 73-80.

Meral, Y.D. (2014). Ortaöğretim Matematik Öğretmenlerinin Eğitim Felsefesi Görüşleri ve Öğretme-Öğrenme Anlayışlarının Yapılandırmacı Öğrenme Ortamı Düzenleme Becerilerine Etkisi. Kocaeli Üniversitesi, Sosyal Bilimler Enstitüsü, Yayınlanmamış Yüksek Lisans Tezi

Oğuz, A. (2011). Öğretmen Adaylarının Demokratik Değerleri ile Öğretme ve Öğrenme Anlayışları. Değerler Eğitimi Dergisi, 9(22), $139-160$

Özüdoğru, S.M. (2010). Beden Eğitimi Öğretmenlerinin Beden Eğitimine Iliş̧kin Felsefi Görüşlerinin Dağılımı. Hacettepe Üniversitesi, Sağlık Bilimleri Enstitüsü, Yayınlanmamış Yüksek Lisans Tezi

Sönmez, V. (2005). Eğitim felsefesi. Ankara: Anı Yayıncılık

Şişman, M. \& Turan, S. (2004). Dünyada Eğitim ve Yöneticilerinin Yetiştirilmesie İlişkin Başlıca Yönelimler ve Türkiye İçin Çıkarılabilecek Bazı Sonuçlar. Türk Eğitim Bilimleri Dergisi, 2(1), 13-26

Tahiroğlu, M. (2014). Hoşgörülü ve Demokratik Bir Sınıf Toplumu Uygulaması. Uluslararası Avrasya Sosyal Bilimler Dergisi, 5 (17), 87-110

Terzi, A. R. (2010). Eğitim Bilimine Giriş (2.baskı). Ankara: Detay Yayıncılık

Toprakçı, E. (2005). Eğitim Üzerine. Ankara: Ütopya Yayınevi

Topses, G. (2012). Davranışçı ve Varoluşçu-Hümanistik Psikolojik Danışma Kuramlarının Ayırtedici ve Örtüşen Nitelikleri. International Journal of New Trends in Arts, Sports\&Science Education, 1(3), 67-75.

Tozlu, N. \& Yayla, A. (2006). Eğitimin Felsefi Temelleri. İçinde, Erçetin, Ş. \& Tozlu, N. (Ed.), Eğitim Bilimine Giriş, Ankara: Hegem Yayınları

Tunca, N., Alkın-Şahin, S., \& Oğuz, A. (2015). Öğretmenlerin eğitim inançları ile meslekî değerleri arasındaki ilişki. Kalem Eğitim ve insan Bilimleri Dergisi, 5 (1), 11-47. 
Tuncel, G. (2004). Oğretmenlerin Kendi Eğitim Felsefelerini Inşa Etmeleri Uzerine. Kazım Karabekir Eğitim Fakültesi Dergisi, sayı 10

Turgut, ì. (1991). Eğitim Üzerine Felsefi Bir Deneme. İzmir: Bilgehan matbaası.

Türkoğlu, A. (1997). Eğitim Bilimine Giriş. Ankara: Memleket

Uğurlu, C.T. \& Çalmaşur, H. (2017). Öğretmenlerin ve Öğretmen Adaylarının Eğitim İnançlarına İlişkin Görüşleri: Bir Karma Yöntem Çalışması. Adıyaman Üniversitesi Sosyal Bilimler Enstitüsü Dergisi, 25, 230-273

Üredi, L. (2009). Eğitimin Felsefi Temelleri. Eğitim Bilimine Giriş (Editör: L. Kıroğlu ve C. Elma) Ankara: Pegem Akademi.

Yanpar-Yelken., Üredi, L., Tanrıseven, I. \& Kılıç, F. (2010). İlköğretim Müfettişlerinin Yapılandırmacı Program ile Öğretmenlerin Yapılandırmacı Öğrenme Ortamı Oluşturma Düzeylerine İlişkin Görüşleri. Ç.Ü. Sosyal Bilimler Enstitüsü Dergisi, 19(2), 31-46

Yazıcı T. (2017). Müzik Öğretmeni Adaylarının Eğitim Felsefesi İnançları. Kastamonu Eğitim Dergisi, 25(2)

Yılmaz, G. (2015). İsmet İnönü’nün Eğitim Felsefesi (Konuşmaları ve Yazdıkları Işığında Nitel Bir Analiz). Ege Üniversitesi Sosyal Bilimler Enstitüsü, Yayınlanmamış Yüksek Lisans Tezi

Yılmaz, K., \& Tosun, M.F. (2013). Öğretmenlerin eğitim inançları ile öğretmen öğrenci ilişkilerine yönelik görüşleri arasındaki ilişki. Eğitim ve Öğretim Araştırmaları Dergisi, 2(4), 205-218.

Yılmaz, K., Altınkurt Y., Çokluk Ö. (2011). Eğitim İnançları Ölçeği'nin Geliştirilmesi: Geçerlik ve Güvenirlik Çalışması. Kuram ve Uygulamada Eğitim Bilimleri, 11(1), 335-350

Yokuş, T. (2016). Müzik Öğretmeni Adaylarının Benimsedikleri Eğitim Felsefelerinin Çeşitli Değişkenler Açısından İncelenmesi. MSKU Eğitim Fakültesi Dergisi, 3(1) 